\title{
Ambiances
}

anbiances Environnement sensible, architecture et espace urbain Éditos | 2013

\section{Into the sensory world}

Ouverture au monde sensible

Jean-Paul Thibaud

\section{(2) OpenEdition}

Journals

\section{Electronic version}

URL: http://journals.openedition.org/ambiances/188

DOI: 10.4000/ambiances.188

ISSN: 2266-839X

\section{Publisher:}

Direction Générale des Patrimoines - DAPA - MCC, UMR 1563 - Ambiances Architectures Urbanités (AAU)

\section{Electronic reference}

Jean-Paul Thibaud, «Into the sensory world», Ambiances [Online], Editos, Online since 12 February 2013, connection on 22 September 2020. URL : http://journals.openedition.org/ambiances/188 ; DOI : https://doi.org/10.4000/ambiances. 188

\section{This text was automatically generated on 22 September 2020}

\section{cc) (i) () $\Theta$}

Ambiances is licensed under a Creative Commons Attribution-NonCommercial-NoDerivatives 4.0 International License. 


\title{
Into the sensory world
}

\author{
Ouverture au monde sensible
}

\author{
Jean-Paul Thibaud
}

1 The launch of the Ambiances Review marks an important step in the recognition of the sensory world as a field of pluridisciplinary research, as a present issue for architectural and urban design, and as an arena for artistic experimentation and creation. Its goals are ambitious and there will be plenty to do for all those with an interest in the sensory environment of inhabited space.

2 This first issue reflects the scale of our task, such is the diversity and variety of frames of thinking displayed here, of possible prospects for this subject and the many study projects set in motion. You may read here a proposal for a new aesthetic of atmospheres, a piece on the sensory ethnographics of a public space in Paris, an attempt to characterize urban space in the light of various forms of pedestrian mobility, an attentive reading of a narrative of insular ambiances, and the phenomenal description of a gated community in Cairo. Furthermore, a critique of two books on the sensory city marks the start of another section in the review.

3 All these exploratory essays offer pointers to the purpose of the review and to lines of current research. These initial articles also show how much the far-reaching changes in the territories and habitats of contemporary life demand new approaches, new models of intelligibility to give an account of them. Yet this is no more than a rough sketch. Other forms of input, other approaches will gradually follow to fill in the picture and substantiate the plurality to which the review lays claim.

4 We would also draw your attention to the deliberately bilingual character of our publication, our aim being to develop even further encounters and exchange between French and English-speaking research. It would be a mistake to underestimate the importance of language in a field as sensitive as ours! In these days of hybridization and translation, it is increasingly vital to guard against any form of "methodological nationalism" or linguistic single-mindedness.

5 Lastly the growing interest for the world of the senses is a good reason to make full use of various media, archives and sensory materials arising out of research. The 
Ambiances Review is consequently determined to accommodate all sorts of sound, video or photographic recordings, if they prompt questions or nourish investigation.

6 Jean-Paul Thibaud on behalf of the editorial board. 